\title{
Molecular studies on preproghrelin gene: Alternative splicing, obestatin effects, coding region and variants
}

Letícia Koczicki, Laysa Toschi Martins, Luccas Matheus Wischral, Andressa de Souza Klingenfus, André Bittencourt Lorusso, Karen Sumire Kubo and Henrique Ravanhol Frigeri*

School of Life Sciences, Pontifical Catholic University of Parana, Curitiba, Brazil

\section{Introduction}

Obestatin is a 23-amino acid peptide produced by posttranslational modifications of the 117-residue preproprotein called Ghrelin and Obestatin Prepropeptide (GHRL) that undergoes cleavages, generating obestatin, ghrelin and a signal peptide. Despite being derived from the same prepropeptide, obestatin and ghrelin have opposite effects on weight gain, food intake, energy balance and gastric emptying [1,2]. While ghrelin has orexigenic properties (such as increased fat deposition and inhibition of insulin secretion), obestatin acts on anorexigenic effects slowing gastric emptying and suppressing food intake [3]. The physiological role of obestatin is considered by many authors multifunctional, acting in several tissues and promoting effects besides the antagonistic effects to ghrelin [3]. First, the G protein-coupled receptor-39 (GPR39) was indicated as an obestatin cognate ligand receptor, but this is not supported by several authors, indicating the need for new and more accurate research [4-6]. However, that peptide clearly shows an important role in metabolism involved with anti-inflammatory and cardioprotective effects [7-19]. Furthermore, polymorphisms found in GHRL gene are also being associated with different clinical conditions [20-23]. Thus, this article intends to describe examples of variants found in the GHRL coding gene obestatin-associated and to report the variants produced by alternative splicing processes in the whole gene.

\section{Examples of obestatin-associated effects}

Several physiological effects have been described for obestatin, however, the mechanisms are complex and need a better investigation. In the gastrointestinal system, obestatin acts increasing the secretion of enzymes released by the pancreas. Furthermore, that hormone reduces jejuni's motility, gastric emptying, consequently reducing food intake and body weight [3]. Moreover, other mechanisms were proposed, such as those involved in the central nervous system and its association with positive effects on memory retention, increasing sleep promotion and inducing anxiolytic activity, opposing the effect of ghrelin on anxiety $[1,8]$. Obestatin also participates in cell proliferation. That peptide stimulates the primary cultures of human retinal epithelial cells (hRPE) [9], relevant effects on cell proliferation, apoptosis and progesterone releasing by ovarian cells [10]. Studies have shown that obestatin does not alter growth hormone $(\mathrm{GH})$ and corticosterone secretion, but it was associated with vasopressin decreasing plasma levels, evidencing an important role in homeostatic regulation $[11,12]$. Obestatin has also been investigated in type 2 Diabetes mellitus, obesity, atherosclerosis, anorexia nervosa and cancer studies by different mechanisms $[3,24]$.

\section{GHRL polymorphisms - obestatin coding region}

Up to now, 19 polymorphisms were found in the obestatin coding region, based on data obtained from dbSNP (Table 1). After researching in Pubmed, Scielo and Science Direct databases, only rs4684677, rs186599567 and rs149447194 were found described by authors.

\section{The polymorphism rs4684677}

The genetic variation Gln90Leu (Q90L, T/A, rs4684677) is a single nucleotide polymorphism (SNP) that leads to the exchange of the amino acid located at position 90 of preproghrelin in isoform 1 . This variant was firstly identified in a German association study. The variant showed a significant difference $(p=0.011)$ among extremely obese children and adolescents and students of University of Marburg with normal weight [13].

Furthermore, it was suggested that rs4684677 probably contributes to autoimmune thyroid disease predisposition in a case-control study that investigated polish children $(p=0.002)$ [14], as well as increased women's waist circumference in a Spanish sample population [15]. No significant association was observed in a Brazilian population sample in a study conducted for gestational diabetes [16].

\section{The polymorphisms rs149447196 and rs186599567}

The polymorphism rs149447196 is characterized by G/A substitution, silent mutation (Asn $\rightarrow$ Asn) which corresponds to the $77^{\text {th }}$ position in the preproghrelin, isoform $1\left(2^{\text {nd }}\right.$ amino acid position in the obestatin peptide). The polymorphism rs 186599567 is an A/G gene variant responsible for changing the 98th amino acid (Leu $\rightarrow$ Pro) of the isoform 1. This position is essential for the recognition of obestatin post-translational sites. Both rs149447196 and rs186599567 were investigated in association with congenital anorectal malformation and Hirschsprung disease, demonstrating the possibility of association [17].

\section{Alternative splicing variants}

A research in the NCBI nucleotide database showed variants generated from alternative splicing in the preproghrelin gene. Overall, there are 11 variants identified by biological evidence (numbered 1 , $2,3,4,5,8,9,10,11,12$ and 13) and another 2 (called X1 and X2)

${ }^{\star}$ Correspondence to: Henrique Ravanhol Frigeri, School of Life Sciences, Pontifical Catholic, University of Parana, Curitiba, Parana, Brazil Rua Imaculada Conceição, 115580215-901 Curitiba, PR, Brazil, E-mail: henrique.frigeri@gmail. com, henrique.frigeri@pucpr.br

Received: May 15, 2019; Accepted: June 19, 2019; Published: June 24, 2019 
Table 1. Polymorphisms in obestatin coding regions and general characteristics

\begin{tabular}{|c|c|c|c|c|}
\hline Variant & NTe & AAp & AA and characteristics & Taqman code \\
\hline rs 1013246671 & $\mathrm{C} / \mathrm{T}$ & 77 & Asn-Ser; Missense; Polar & NA \\
\hline rs 149447194 & $\mathrm{G} / \mathrm{A}$ & 77 & Asn-Asn; Silent; Polar & C_169849178_10 \\
\hline rs 752298108 & $\mathrm{C} / \mathrm{T}$ & 78 & Ala-Thr; Missense; Non-polar-Polar & NA \\
\hline rs755045075 & GGG/- & 79 & Pro/-; Indel; & NA \\
\hline rs781599822 & $-/ \mathrm{G}$ & 80 & -/X; Indel; & NA \\
\hline rs 201358681 & $\mathrm{~A} / \mathrm{G}$ & 80 & Phe-Ser; Missense; Non-polar-Polar & C_191183461_10 \\
\hline rs 1044457750 & $-/ \mathrm{C}$ & 85 & Lys-Asn; Indel; Basic-Polar & NA \\
\hline rs 376322935 & $\mathrm{~A} / \mathrm{G}$ & 86 & Leu-Pro; Missense; Non-polar & NA \\
\hline rs 751003045 & $\mathrm{C} / \mathrm{A}$ & 88 & Gly-Trp; Missense; Non-polar & NA \\
\hline rs 765646482 & $\mathrm{C} / \mathrm{G} / \mathrm{T}$ & 88 & Gly-Gly; Silent; Non-polar & NA \\
\hline rs 376856625 & $\mathrm{C} / \mathrm{T}$ & 89 & Val-Ile; Missense; Non-polar & NA \\
\hline rs 753863091 & $\mathrm{G} / \mathrm{A}$ & 90 & Gln-*; Stop Gained; & NA \\
\hline rs4684677 & $\mathrm{T} / \mathrm{A}$ & 90 & Gln-Leu; Missense; Polar-Non-polar & C_25607748_10 \\
\hline rs 372665020 & $\mathrm{C} / \mathrm{T}$ & 90 & Gln-Gln; Silent; Polar & NA \\
\hline rs781508813 & $\mathrm{G} / \mathrm{T}$ & 93 & Gln-Trp; Missense; Polar-Non-polar & NA \\
\hline rs377110254 & $\mathrm{G} / \mathrm{C}$ & 94 & His-Asp; Missense; Basic-Acid & NA \\
\hline rs5444937594 & $\mathrm{C} / \mathrm{G} / \mathrm{T}$ & 95 & Ser-Asn; Missense; Polar-Acid & NA \\
\hline rs 774405407 & $\mathrm{G} / \mathrm{A}$ & 96 & Gln-*; Stop Gained & NA \\
\hline rs 186599567 & $\mathrm{~A} / \mathrm{G}$ & 98 & Leu-Pro; Missense; Non-polar & C_181918670_10 \\
\hline
\end{tabular}

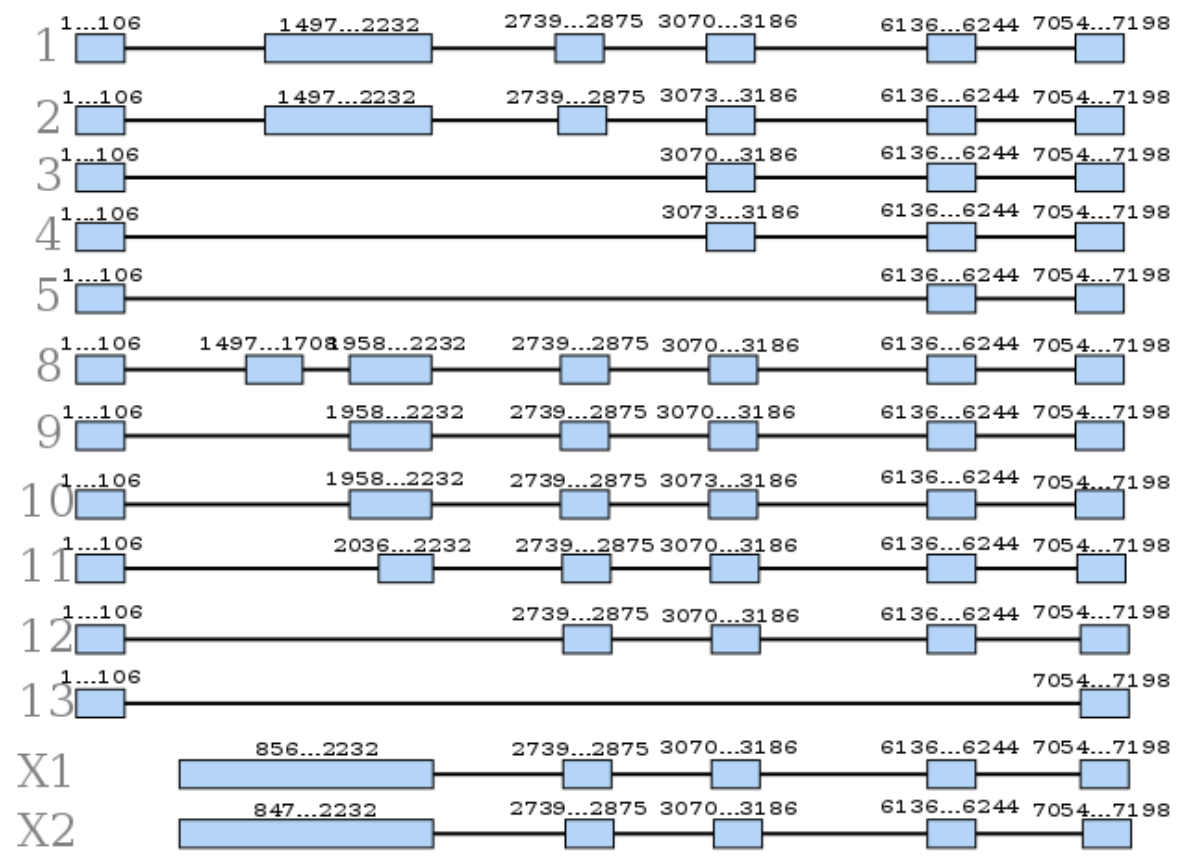

Figure 1. Regions transcribed from each of the variants of the preproghrelin gene. The numbers above the boxes mean the position of the nucleotides in the gene

identified by the computational prediction method Gnomon [18]. The variants have different sizes and differ from each other by including and/or excluding some exonic regions, as shown in Figure 1.

According to the NCBI nucleotide database, variants $8,9,11$ and 12 contain the ligands ghrelin-28 and obestatin, differing from variant 1 only in the 5' UTR. Variants 2 and 10 are constituted by an alternate in-frame splicing site when compared with variant 1 . These isoforms contain the ghrelin-27 and obestatin ligands and differ from each other in the $5^{\prime}$ UTR.

Variants 3 and 4 lack two exons, while variant 5 lacks three exons in comparison to variant 1: all three are shorter variants but retain the reading frame. Variant 13 is classified as non-coding because it does not meet RefSeq criteria and lacks several exons present in variant 1.

Seim and colleagues [25] studied different amplicons of the ghrelin gene and were able to show multiple transcript variants originated by alternative splicing in different tissues, with the largest variety found in the stomach. However, the biological role of these variants is not fully elucidated, requiring further studies in the area.

\section{Conclusion}

In this brief report, we analyzed aspects of the portion of the GHRL gene coding for obestatin, its physiological role and some polymorphisms associated with clinical characteristics. In addition, once the role of transcript variants is still unknown, we searched 
on databases to describe them in the whole gene, making it more accessible, updated and clearer to interested readers and researchers.

\section{Authors and contributions}

Study concept and design: LK, LTM (Ph.D.) and HRF (advisor, Ph.D.). Acquisition of data: LK, AdSK and ABL. Drafting the manuscript (and figure design and evaluation): LK, LTM, LMW and HRF. Critical revision of the manuscript for important intellectual content: LK, LTM, LMW, AdSK, ABL, KSK, HRF.

\section{Conflict of interest disclosures} article.

The authors declare no potential conflicts of interest relevant to this

\section{Acknowledgements}

We are thankful to the School of Life Sciences and the Biotechnology course of the Pontifical Catholic University of Parana for its support.

\section{References}

1. Carlini VP, Schiöth HB, deBarioglio SR (2007) Obestatin improves memory performance and causes anxiolytic effects in rats. Biochem Bioph Res Co 352: 907-912.

2. Zhang JV, Ren P, Avsian-Kretchmer O, Luo C, Rauch R, et al. (2005) Obestatin, a Peptide Encoded by the Ghrelin Gene, Opposes Ghrelin's Effects on Food Intake. Science 310: 996. [Crossref]

3. Lacquaniti A, Donato V, Chirico V, Buemi A, Buemi M (2011) Obestatin: an interesting but controversial gut hormone. Ann Nutr Metab 59: 193-199.

4. Chartrel N, Alvear Perez R, Leprince J, Iturrioz X, Reaux-Le Goazigo A, et al. (2007) Comment on "Obestatin, a peptide encoded by the ghrelin gene, opposes ghrelin's effects on food intake" Science 315: 766c-766c.

5. Lauwers E, Landuyt B, Arckens L, Schoofs L, Luyten W (2006) Obestatin does not activate orphan $\mathrm{G}$ protein-coupled receptor GPR39. Biochem Bioph Res Co 351: 21-25.

6. Holst B, Egerod KL, Schild E, Vickers SP, Cheetham S, et al. (2007) GPR39 signaling is stimulated by zinc ions but not by obestatin. Endocrinology 148: 13-20.

7. Gesmundo I, Gallo D, Favaro E, Ghigo E, Granata R (2013) Obestatin: A New Metabolic Player in the Pancreas and White Adipose Tissue. International Union of Biochemistry and Molecular Biology 65: 976-982.

8. Tang SQ, Jiang QY, Zhang YL, Zhu XT, Shu G, et al. (2008) Obestatin: its physicochemical characteristics and physiological functions. Peptides 29: 639-645.

9. Camiña JP, Campos JF, Caminos JE, Dieguez C, Casanueva FF (2007) Obestatinmediated proliferation of human retinal pigment epithelial cells: regulatory mechanisms. J Cell Physiol 211: 1-9.

10. Mészárosová M, Sirotkin AV, Grossmann R, Darlak K, Valenzuela F (2008) The effect of obestatin on porcine ovarian granulosa cells. Anim Reprod Sci 108: 196-207.
11. Bresciani E, Rapetti D, Dona F, Bulgarelli I, Tamiazzo L, et al. (2006) Obestatin inhibits feeding but does not modulate $\mathrm{GH}$ and corticosterone secretion in the rat. $J$ Endocrinol Invest 29: RC16-RC18.

12. Samson WK, Yosten GL, Chang JK, Ferguson AV, White MM (2008) Obestatin inhibits vasopressin secretion: evidence for a physiological action in the control of fluid homeostasis. J Endocrinol 196: 559-564.

13. Hinney A, Hoch A, Geller F, Schafer H, Siegfried W, et al. (2002) Ghrelin gene: identification of missense variants and a frameshift mutation in extremely obese children and adolescents and healthy normal weight students. $J$ Clin Endocrinol Metab 87: 2716 .

14. Moniuszko A, Wawrusiewicz-Kurylonek N, Bossowska A, Gościk J, Włodzimierz L, et al. (2015) The association between rs4684677 T/A polymorphism in preproghrelin gene and predisposition to autoimmune thyroid diseases in children. Autoimmunity $\mathrm{p}$ : 1-5. [Crossref]

15. Mora M, Adam V, Palomera E, Blesa S, Díaz G, et al. (2015) Ghrelin Gene Variants Influence on Metabolic Syndrome Components in Aged Spanish Population. Plos One 10: 1-17. [Crossref]

16. Rocha RA, Frigeri HR, dos Santos-Weiss ICR, Réa RR, de Souza EM, et al. (2014) Preproghrelin polymorphism Q90L (rs4684677) in gestational diabetes. Arq Bras Endocrinol Metab p: 58.

17. Gao H, Wang D, Zhao X, Mi J, Bai Y, et al. (2015) Relationship of Ghrelin gene polymorphism with congenital anorectal malformation and Hirschsprung disease. Zhonghua Wei Chang Wai Ke Za Zhi 18: 707-172.

18. Souvorov A, Kapustin Y, Kiryutin B, Chetvernin V, Tatusova T, et al. (2002) Gnomon NCBI eukaryotic gene prediction tool. National Center for Biotechnology Information, Bethesda.

19. Pradhan G, Wu S, Lee JH, Kanikarla P, Guo S, et al. (2017) Obestatin stimulates glucose-induced insulin secretion through ghrelin receptor GHS-R. Sci Rep 7: 979.

20. Green BD, Grieve DJ (2018) Biochemical properties and biological actions of obestatin and its relevence in type 2 diabetes. Peptides 100: 249-259.

21. Ghaleh TD, Skandari SS, Najafipour R, Rashvand Z, Darabi M, et al. (2017) Association of 2604G/A and 2501A/C Ghrelin and Obestatin Prepropeptide Gene Polymorphisms with Polycystic Ovary Syndrome. Biochem Genet 56: 116-127.

22. Llamas-Covarrubias IM, Llamas-Covarrubias MA, Martinez-López E, Zepeda-Carrillo EA, Rivera-León EA, et al. (2017) Association of A-604G ghrelin gene polymorphism and serum ghrelin levels with the risk of obesity in a mexican population. Mol Biol Rep 44: 289-293.

23. Suchankova P, Yan J, Schwandt ML, Stangl BL, Jerlhag E, et al. (2017) The Leu72Met polymorphism of the prepro-ghrelin gene is associated with alcohol consumption and subjective responses to alcohol: Preliminary findings. Alcohol Alcoholism 52: 425-430.

24. Ren AJ, Guo ZF, Wang YK, Lin L, Zheng X, et al. (2009) Obestatin, obesity and diabetes. Peptides 30: 439-444.

25. Seim I, Collet C, Herington AC, Chopin LK (2007) Revised genomic structure of the human ghrelin gene and identification of novel exons, alternative splice variants and natural antisense transcripts. BMC genomics 8: 298.

Copyright: (C2019 Koczicki L. This is an open-access article distributed under the terms of the Creative Commons Attribution License, which permits unrestricted use, distribution, and reproduction in any medium, provided the original author and source are credited. 